Brazilian Journal

of Chemical

Engineering

\title{
DISRUPTION OF Nannochloropsis gaditana (EUSTIGMATOPHYCEAE) RIGID CELL WALL BY NON-THERMAL PLASMA PRIOR TO LIPID EXTRACTION AND ITS EFFECT ON FATTY ACID COMPOSITION
}

\author{
Ângelo P. Matos ${ }^{1,4^{*}}$, Marina S. Teixeira ${ }^{1}$, Flávia M. P. S. Corrêa ${ }^{2}$, \\ Marina M. Machado ${ }^{3}$, Rhuamm I. S. Werner ${ }^{4}$, Ana C. Aguiar ${ }^{4}$, Anelise L. V. Cubas ${ }^{3}$, \\ Ernani S. Sant'Anna ${ }^{1}$ and Elisa H. S. Moecke ${ }^{1,4}$ \begin{abstract}
E-mail: angelosotam@gmail.com - ORCID: 0000-0002-6600-2290; ORCID: 0000-0002-2663-6010
${ }^{2}$ Universidade de São Paulo, Instituto Oceanográfico, São Paulo, SP, Brasil. ORCID: 0000-0001-6081-0388

${ }^{3}$ Universidade do Sul de Santa Catarina, Laboratório de Plasma, Palhoça, SC, Brasil. ORCID: 0000-0002-7124-9503

${ }^{4}$ Universidade do Sul de Santa Catarina, Laboratório de Engenharia Ambiental, Palhoça, SC, Brasil.
\end{abstract} \\ ${ }^{1}$ Universidade Federal de Santa Catarina, Departamento de Ciência e Tecnologia de Alimentos, Florianópolis, SC, Brasil.
}

(Submitted: February 20, 2019 ; Revised: June 25, 2019 ; Accepted: August 1, 2019)

\begin{abstract}
This study assessed the effect of non-thermal plasma (NTP) on Nannochloropsis gaditana cell rupture and subsequent lipid extraction. Micrograph images showed that the surface of original $N$. gaditana cells appeared smooth and had no apparent holes, whereas after NTP the cells showed a non-uniform apparently fractured surface with many pores and large splits. Maximum lipid recovery from $N$. gaditana cells $(\sim 19 \%)$ for NTP-assisted rupture was observed at 10 min, similar to extraction after 10 min sonication (19.0\%). The lipid recovery after both pretreatments (average 19.0\%) was 2-fold higher than the control treatment (no pretreatment $9.5 \%$ ). In addition, lipids from unruptured algal cells were mainly composed of $\omega$-3polyunsaturated fatty acids ( $\sim 31 \%$ of total fatty acids), while lipids after NTP were predominantly composed of saturated fatty acids $(36.0 \%$ of total fatty acids), which could be advantageous for biodiesel production. This study demonstrates an alternative approach based on NTP-technology for algal cell rupture prior to lipid extraction with potential uses for algal biodiesel production.

Keywords: Microalgae; Plasma-induced chemical changes; Cell disruption; Lipid recovery; Biodiesel properties.
\end{abstract}

\section{INTRODUCTION}

Microalgae have been identified by many researchers as a promising feedstock for biofuel production (Chisti, 2007; Phukan et al., 2011; Franz et al., 2013; Jazzar et al., 2015). In fact, several species of microalgae are able to accumulate carbohydrates and lipids which can be chemically converted into biofuels (Jazzar et al., 2015; Siqueira et al., 2016). Among them, Nannochloropsis gaditana belonging to the Eustigmatophyceae genus, is particularly interesting because of its high growth rate, lipid productivity, and ability to synthesize high value chemicals, such as pigments (carotenoids) and fatty acids with medium $\left(\mathrm{C}_{16}\right.$ and $\left.\mathrm{C}_{18}\right)$ and long $\left(\mathrm{C}_{20: 5 \infty 3}\right)$ chain carbons (Matos et al., 2015; Mitra et al., 2015; Matos et al., 2016; Matos, 2017). Production and extraction of intracellular metabolites from microalgae involve extensive processing steps that start with algal cultivation, algal biomass recovery or harvesting through separation of the biomass from the carrier media, followed by further processing such

\footnotetext{
* Corresponding author: Ângelo P. Matos - E-mail: angelosotam@gmail.com
} 
as dewatering, drying, cell disruption, extraction and product purification (Show et al., 2013). According to Günerken et al. (2015), the complete disruption of the algal cell wall prior to product recovery has been shown to be critical for successful process-scale lipid extraction from wet algal biomass. Feasible ways of extracting intracellular products are disruptions by physical, chemical or enzymatic methods to release the intracellular oil into the external medium (Mendes Pinto et al., 2001; Yap et al., 2015). A range of cell rupture techniques, including high pressure homogenization (Samarasinghe et al., 2012; Yap et al., 2015), ultrasonication (Lee et al., 2010; Halim et al., 2012), microwave heating (Lee et al., 2010; McMillan et al., 2013), bead milling (Postma et al., 2015) and osmotic shock (Lee et al., 2010) have been tested on algal suspensions and all have generally been shown to have a positive effect on lipid extraction.

With the emergence of biomass in chemical processes, much effort has been focused on nonthermal technologies, including atmospheric plasma, pulse electric field, ultrasound, and microwaves (Jérome, 2016) and more recently, non-thermal plasma (NTP) technology. NTP is an ionized gas produced by high-voltage electric discharge that causes formation and self-propagation of an avalanche of ionized chemical species and electrons as a result of an interaction between ions from the plasma source and the media (Gaunt et al., 2006; Liao et al., 2017; Cubas et al., 2019). The use of NTP is a potential approach for diverse applications, including industrial sterilization (Alkawareek et al., 2014), pollution control (Kim, 2004), polymer science (Pandiyaraj et al., 2015), food safety (Ragni et al., 2010; Ma et al., 2015), biomedicine (Zhang et al., 2014) and nanoscience (Graham and Stalder, 2011). NTP is emerging as a promising biomass route to synthesize biofuels, such as bioethanol (Benoit et al., 2012; Delaux et al., 2016), and we have investigated the use of NTP for the production of biodiesel from waste frying oil, allowing fast reaction times and easy separation of the final product (Cubas et al., 2016; Istadi et al., 2009). Despite the benefits of NTP for biofuel production, the energy consumption of NTP is the main cost driver, while its long-term reliability and effectiveness for biofuel production are still unknown (Jérome, 2016; Zhang et al., 2017).

In this study we evaluated the use of NTP as an alternative method to disrupt algal cell walls prior to lipid extraction, which to the best of our knowledge has not yet been explored in the field of the algal bioprocess. The algal cell wall is a robust structure that completely encloses the cytoplasm and allows the cell to increase its turgor pressure without bursting. Composition and multiple variations of the cell wall distinguish algae from each other (Borowitzka and Moheimani, 2013). We choose the marine alga Nannochloropsis gaditana as the biomass for our NTP experiments due to its rigid cell wall and high amount of membrane-bound eicosapentaenoic acid (Yap et al., 2015). Furthermore, the spherical shape and small size (1-2 $\mu \mathrm{m})$ of Nannochloropsis cells make it especially difficult to lyse and mechanically rupture its cell wall. The aims of the present study are: $i$ ) to apply NTP on algal biomass and subsequently determine the lipid recovery, as well as to identify the main fatty acids composition; $i$ ) to examine the algal cell wall subjected to NTP using direct microscopy techniques such as laser scanning confocal microscope and scanning electron microscopy; and iii) to estimate the biodiesel physical properties using empirical formulas.

\section{METHODOLOGY}

\section{Microalgae cultivation}

Marine species $N$. gaditana (strain BMAK 130) was kindly supplied by the Banco de Micro-organismos Aidar \& Kutner (BMA\&K) of the Oceanographic Institute at the University of São Paulo (USP). This microalga was cultivated in autoclaved F/2 seawater medium suitable for marine algae (Guillard, 1975). The culture was developed using inverted conical photobioreactors $(5.5 \mathrm{~L})$ with a working volume of $3.5 \mathrm{~L}$ and incubated at room temperature $\left(26 \pm 2{ }^{\circ} \mathrm{C}\right)$, sparing with saturated air- $\mathrm{CO}_{2}$, with a photoperiod of $12 \mathrm{~h}: 12 \mathrm{~h}$ light/dark provided by fluorescent lamps (Osram Universal, Brazil), under a light intensity of $80 \mu \mathrm{mol} \mathrm{m} \mathrm{m}^{-2} \mathrm{~s}^{-1}$. When algae reached the stationary phase (10 days of cultivation), a sample was harvested by centrifugation at $4000 \times \mathrm{g}$ for $20 \mathrm{~min}$. washed with ammonium formate to remove salts from the algal biomass (Zhu and Lee 1997) and centrifuged again (Nova Técnica centrifuge, Piracicaba, Brazil).

\section{Non-thermal plasma reactor}

The in-house built NTP reactor is a cylindrical discharge reactor with point-to-plate geometry operated at atmospheric pressure (Figure 1). The cylinder is made of glass (radius of $22 \mathrm{~mm}$, height of $70 \mathrm{~mm}$ ). The active electrode is a hollow, stainless steel needle with the tip placed $10 \mathrm{~mm}$ above the $40 \mathrm{~mL}$ solution surface. Argon gas is fed through the needle into the reactor at a flow rate of $1 \mathrm{~L} \mathrm{~min}^{-1}$. The ground electrode is a tungsten wire (diameter $1.0 \mathrm{~mm}$ ). The top of the glass cylinder is closed by a Teflon cover equipped with a gas outlet. The reactor is fed by a direct current (DC) impedance voltage transformer (60 $\mathrm{Hz}, 220 \mathrm{~V} / 12,000 \mathrm{~V}$ ) purchased from Variac (model ATV-215-MP, São Paulo, Brazil). A tripler voltage equipment composed of 4 diodes and 8 capacitors was used to convert the alternate current (AC) into direct current (DC). An iCEL Manual MD-1000 multimeter 


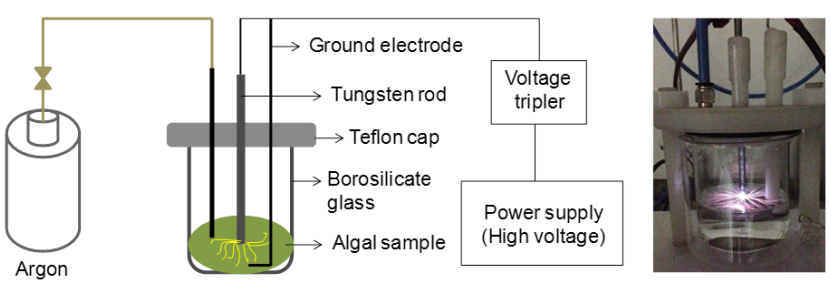

Figure 1. Schematic diagram and a photograph of the non-thermal plasma (NTP) reactor.

was used to monitor the voltage, electrical resistance and current between the discharge gap. The electrical parameters applied for all experiments were $17 \mathrm{kV}$ and $30 \mathrm{~mA}$. Under these conditions, an intense core plasma was formed between the two electrodes, and a luminous plume extended out of the tube end reaching the treated sample. For NTP-treatments, a mixture of $1 \mathrm{~g}$ of algal sample and $40 \mathrm{~mL}$ of water was put in the glass container and placed in the plasma setup.

\section{Sonication}

A sample of $\sim 1.0 \mathrm{~g}$ of the wet algal biomass was mixed in $40 \mathrm{~mL}$ of distilled water and transferred to a Falcon tube and subjected to sonication treatment using an Ultrasonic Cleaner processor (Indaiatuba, São Paulo, Brazil) at a frequency of $20 \mathrm{kHz}$. Algae were separated by centrifugation at 4,000 rpm for 20 min. and the biomass was analyzed for lipid recovery.

\section{Cell rupture quantification via hemocytometry}

Quantification of cell rupture was performed by cell counting, which is accurate and reproducible (Samarasinghe et al., 2012; Yap et al., 2015). The extent of cell disruption was assessed by counting the number of intact cells remaining after NTP using a Neubauer hemocytometer with a $100 \mu \mathrm{m}$ chamber depth. All imaging was performed using an Olympus BX40F4 (Japan) light microscope with 40x object resolution and an Opticam ${ }^{\circledR}$ digital camera attachment.

\section{Scanning electron microscopy}

A scanning electron microscope (SEM) (JEOL JSM-6460LA, Tokyo, Japan) with a tungsten filament electron gun was used to characterize the algal powder surface after NTP treatment at $10-15 \mathrm{kV}$. Algal powder was mounted onto SEM stubs by placing or sputtering them on a carbon double-sided adhesive tape. Excess particles were removed by gentle tapping. Gold coating ( $\sim 10 \mathrm{~nm}$ thick) was done for $2 \mathrm{~min}$. with a Xenosput Sputter Coater (Xenosput XE200, Edwards High Vacuum International, Cambridge, U.K.).

\section{Laser scanning confocal microscope}

A detailed examination of untreated and NTPtreated algal cells was done using direct laser scanning confocal microscopy (LSCM). In parallel, intracellular lipid bodies of NTP-treated algal cells were visualized using Nile Red stain (9-(diethylamino) benzo[a] phenoxazin-5(5H)-one, Sigma - Aldrich), which was prepared as a stock solution of $250 \mathrm{mg} \mathrm{L}^{-1}$ in acetone. One milliliter of algae was centrifuged at $4000 \mathrm{rpm}$ for $10 \mathrm{~min}$ and a pellet was re-suspended in $1 \mathrm{~mL}$ of $20 \%$ DMSO. After vortexing for $10 \mathrm{~min}$ at room temperature, cells were centrifuged at $4000 \mathrm{rpm}$ for $10 \mathrm{~min}$. The pellet was further suspended in $1 \mathrm{~mL}$ of water and vortexed before adding Nile Red stain $(12.5 \mu \mathrm{L})$ and incubating for $5 \mathrm{~min}$ in the dark at room temperature (Ahmad et al. 2013). Stained cells were visualized using a Leica TCS - SP5 laser scanning confocal microscope (Wetzlar, Germany). Images were acquired using a 100x objective (HCX PL APO $\mathrm{CS}$, a numerical aperture of 1.44 - oil immersion objective) with a Leica Type F immersion liquid. Images were taken with a Leica microsystem camera. The acquisition and processing of data were carried out using the LAS AF Lite software.

\section{Lipid extraction and fatty acids analysis}

Intracellular lipids were extracted from dried biomass by maceration of the biomass in a mixture of methanol:chloroform:water (2:1:0.8 v/v/v) and quantified gravimetrically (Bligh and Dyer, 1959).

The fatty acid composition was determined after conversion of the fatty acids to their corresponding methyl esters and separation on a gas chromatograph, model GC-2014 (Shimadzu, Kyoto, Japan), equipped with split-injection port, flame-ionization detector, a Restek a 105 m-long capillary column (ID $=0.25$ $\mathrm{mm}$ ) filled with $0.25 \mu \mathrm{m}$ of $10 \%$ cyanopropylphenyl and $90 \%$ biscyanopropylsiloxane. Injector and detector temperatures were both $260^{\circ} \mathrm{C}$. The oven temperature was initially set at $140^{\circ} \mathrm{C}$ for $5 \mathrm{~min}$, and then programmed at $2.5^{\circ} \mathrm{C} \mathrm{min}^{-1}$. The qualitative fatty acids composition was determined by comparing the retention times of the peaks with the respective fatty acids standards (Sigma, St. Louis, USA). The quantitative composition was obtained by area normalization and expressed as mass percent (IAL, 2005).

\section{Estimation of physical properties of biodiesel}

The key physical properties of biodiesel such as saponification value ( $\mathrm{SV}$, mg $\mathrm{KOH}$ per $\mathrm{g}$ ), iodine value (IV, $\mathrm{gI}_{2}$ per $100 \mathrm{~g}$ ), cetane number $(\mathrm{CN})$, long-chain saturation factor (LCFS, \% wt), cold filter plugging point $\left(\mathrm{CFFP},{ }^{\circ} \mathrm{C}\right)$, degree of unsaturation (DU, \% wt), higher heating value (HHV, MJ kg-1) and oxidative stability $(\mathrm{OS}, \mathrm{h})$ were calculated by using the following empirical formulas (Arora et al., 2016):

$\mathrm{SV}=\frac{\sum 560(\% \mathrm{FA})}{\mathrm{M}_{\mathrm{i}}}$ 


$$
\begin{aligned}
& \mathrm{IV}=\frac{\sum 254 \mathrm{DB} \times(\% \mathrm{FA})}{\mathrm{M}_{\mathrm{i}}} \\
& \mathrm{CN}=\frac{46.3+5458}{\mathrm{SV}-(0.255 \times \mathrm{IV})} \\
& \mathrm{DU}=\mathrm{MUFA}+(2 \times \mathrm{PUFAs}) \\
& \mathrm{LCFS}=(.1 \times \mathrm{C} 16)+(0.5 \times \mathrm{C} 18) \\
& \mathrm{CFFP}=(3.147 \times \mathrm{LCFS})-16.477 \\
& \mathrm{HHV}=49.43-0.041(\mathrm{SV})-0.015(\mathrm{IV}) \\
& \mathrm{OS}=\frac{117.92}{(\% \mathrm{C} 20: 5 \omega 3)+2.59}
\end{aligned}
$$

where $\mathrm{FA}=$ content of each fatty acid component, $\mathrm{M}_{\mathrm{i}}=$ molecular mass of each fatty acid component, $\mathrm{DB}=$ number of double bonds, MUFA $=$ content of monounsaturated fatty acids (percent by weight), PUFAs $=$ content of polyunsaturated fatty acids (percent by weight) and C20:5 $\omega 3$ (eicosapentaenoic acid) represents the 20 carbon chain having five double bonds.

\section{Statistical analysis}

Statistical analysis was performed by applying oneway analysis of variance (ANOVA) and the Tukey test with a $p$-value $<0.05$, using STATISTICA Software (version 7.0) from StatSoft Inc. (2004).

\section{RESULTS AND DISCUSSION}

\section{Effect of non-thermal plasma on lipid and fatty acids content}

Since NTP has been proposed as a potential pretreatment for algal-lipid extraction, the aim of this experiment was to compare the lipid recovery from $N$. gaditana after NTP and after sonication treatments (Figure 2). N. gaditana cells were passed through the NTP and sonication once for 1, 2, 5, 10,15 and 20 min. The amount of lipids extracted was then determined for each sample and related to the measured degree of cell rupture. Lipid recovery from $N$. gaditana cells ranged from 15.4 to $18.7 \%$ using the NTP-assisted method, while with sonication lipid recovery ranged from 15.5 to $21.7 \%$ (Figure 3). Maximum lipid recoveries of about $19 \%$ for NTP-assisted extraction, as well as for sonication were observed at $10 \mathrm{~min}$, which is 2-fold higher than the lipid recovery of about $10 \%$ in control without pre-treatment.

Several mechanisms underlie sonication-induced cell disruption, including for microalgae cell disruption. During a sonication treatment, the energy of high frequency, normally between 18 to $30 \mathrm{kHz}$, initiates a cavitation process propagating microbubbles, which become unstable and implode violently, sending shock waves that disrupt surrounding materials such as cells. The sonication process also results in thermolysis of water around the bubbles, forming highly reactive free radicals $\left(\mathrm{H}^{\bullet}, \mathrm{HO}^{\bullet}\right.$ and $\left.\mathrm{HOO}^{\bullet}\right)$ that react with

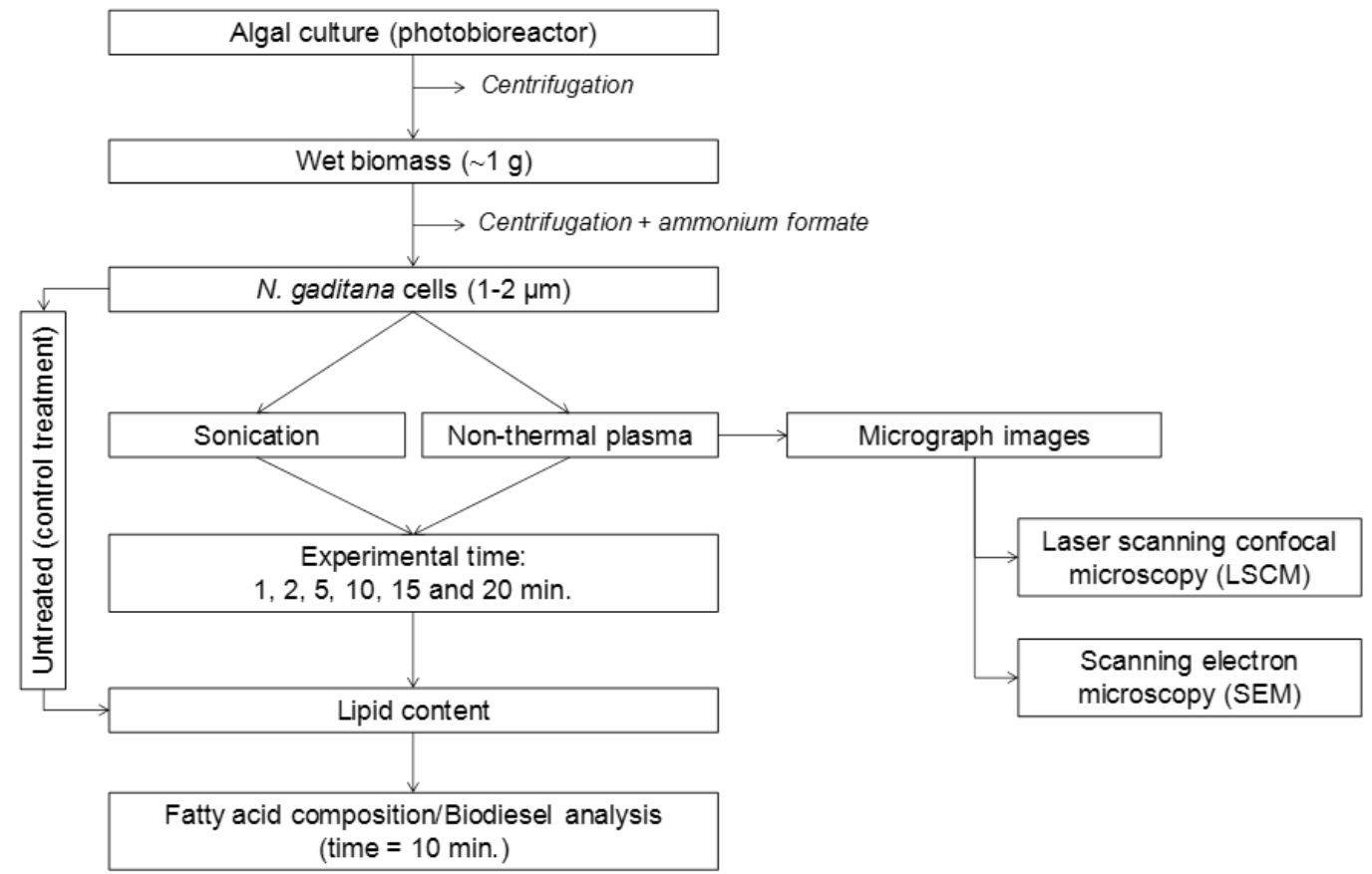

Figure 2. Flow diagram for the usage of sonication and NTP technology as a tool for microalgal lipid extraction. 


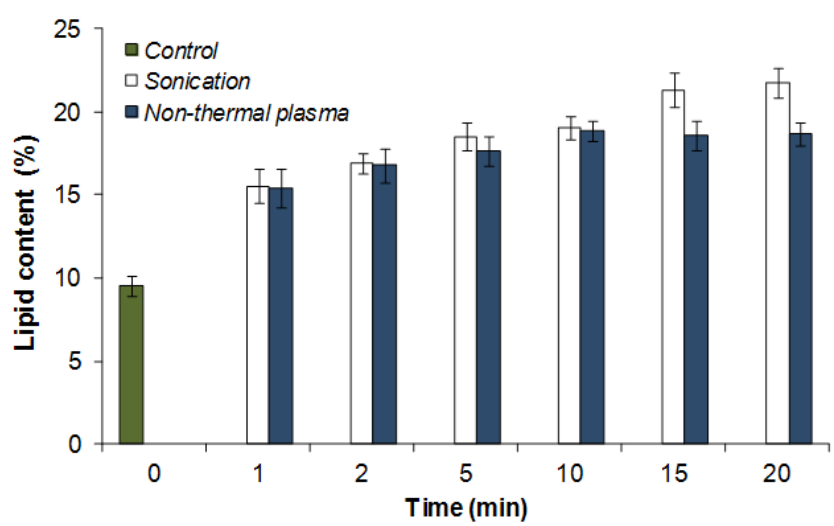

Figure 3. Comparison of the lipid recovery of $N$. gaditana biomass at different times after treatment with either NTP and sonication. At all times lipid recovery is significantly higher $(p<0.05)$ after both pre-treatments (NTP and sonication) compared to control treatment (without any pre-treatment).

the substances in water (Mendes Pinto et al., 2001; Günerken et al., 2015).

We hypothesized that NTP also promotes a disruption of the rigid algal cell wall and releases the intracellular lipid content to the extracellular matrix, thereby increasing lipid recovery. The amount of lipids extracted was indeed correlated with the extent of cell rupture: $9.5 \%$ lipid extraction with $0 \%$ cell rupture, $16.7 \%$ lipid extraction with $25-30 \%$ cell rupture, $18.7 \%$ lipid extraction with $65-70 \%$ cell rupture. However, after 15 and 20 min of NTP, lipid recovery remained constant, 18.5 and $18.6 \%$ (Figure 3), respectively, with a significant population cells (about 20-30\%) remaining intact after NTP treatment.

These findings on the use of NTP for lipid extraction of $N$. gaditana biomass are comparable to observations by Goettel et al. (2013), who applied $40 \mathrm{~min}$ of pulse electric field (PEF) extraction of Auxenochlorella protothecoides biomass and observed higher lipid-yields with algal cell disintegration by PEF than by control treatment. Another study (Martínez et al., 2017) found increased extraction efficiency of pigments such as $C$-phycocyanin from PEF electroporated microalgae ( $S$. platensis). PEF uses an external electric field to induce a critical electrical potential across the cell membrane/wall (Gunerken et al., 2015). Cell disruption by PEF is caused by electromechanical compression and electric field-induced tension inducing pore formation in the membrane/wall. The same authors also mention that PEF does not only destroy the cell wall, but also affects the molecules inside the cells. Though temperature increase is not the mechanism of cell disruption, the increase in bulk temperature during treatment leads to a reduced nutritional value and protein digestibility (Janczyk et al., 2005) and an increased extraction of lipids (Puértolas et al., 2016).
With regard to the fatty acid compositions of $N$. gaditana biomass (Table 1), the control test (no pretreatment) showed a high content in PUFAs of $31.4 \%$ of the total fatty acids, which is comparable to sonication pretreatment (PUFAs $=28.0 \%$ of the total fatty acids), mainly consisting of eicosapentaenoic acid (EPA, C20:5 ๑3). Interestingly, the $₫-3$ PUFAs, especially C20:5 $₫ 3$ decreased from $31.4 \%$ (control test) to $11.0 \%$ when NTP was applied. In addition, a noticeable amount of saturated fatty acids (SFAs), mainly palmitic acid $(\mathrm{C} 16: 0,36.0 \%$ of the total fatty acids), was formed when NTP-assisted extraction was employed. It appears that NTP-treatment of $N$. gaditana biomass stimulates the formation of SFAs. An increased production of SFAs was also observed by Yepez et al. (2016) when using high-voltage atmospheric cold plasma (HVACP) in soybean oil hydrogenation, while the unsaturated fatty acids were chemically modified without the formation of transfatty acids.

The mechanism of the NTP-induced chemical changes in fatty acid composition during the application of NTP to algal biomass is not known, but it is conceivable that the high-energy atmosphere of the plasma facilitates breakage of double bonds, which will result in the formation of fatty acids with single bonds (Cubas et al., 2016; Cubas et al., 2019). This phenomenon may be attributed to the presence of $\mathrm{H}^{+}$and $\mathrm{OH}^{-}$molecules that causes dissociation, ionization and vibrational/rotational excitation of the polyunsaturated fatty acids, which will lead to

Table 1. Main fatty acids present in $N$. gaditana biomass (\%).

\begin{tabular}{lccc}
\hline & \multicolumn{3}{c}{ Treatment } \\
\cline { 2 - 4 } & Control & $\begin{array}{c}\text { Sonication } \\
(\mathbf{1 0} \text { min.) }\end{array}$ & $\begin{array}{c}\text { Non-thermal } \\
\text { plasma (10 min.) }\end{array}$ \\
\hline C12:0 & $1.1 \pm 0.1$ & $0.9 \pm 0.1$ & $0.5 \pm 0.1$ \\
C14:0 & $5.4 \pm 0.3$ & $7.2 \pm 0.9$ & $5.2 \pm 0.7$ \\
C16:0 & $19.4 \pm 2.0$ & $20.0 \pm 1.0$ & $36.0 \pm 1.2^{\mathrm{a}, \mathrm{b}}$ \\
C18:0 & $2.6 \pm 0.9$ & $1.4 \pm 0.5$ & $1.4 \pm 0.2$ \\
$\Sigma$ SFA & $26.1 \pm 3.0$ & $31.7 \pm 2.2$ & $44.6 \pm 2.0$ \\
C15:1 & $0.8 \pm 0.1$ & $0.7 \pm 0.1$ & $0.7 \pm 0.1$ \\
C16:1 & $22.4 \pm 2.0$ & $22.5 \pm 0.6$ & $22.8 \pm 0.4$ \\
C18:1 & $2.8 \pm 0.3$ & $5.8 \pm 0.4$ & $9.7 \pm 0.8^{\mathrm{a}, \mathrm{b}}$ \\
C22:1 & $6.0 \pm 0.5$ & $2.9 \pm 0.1^{\mathrm{a}}$ & $2.3 \pm 0.1^{\mathrm{a}}$ \\
$\Sigma$ MUFA & $32.0 \pm 2.0$ & $33.6 \pm 1.0$ & $36.0 \pm 1.2$ \\
C18:3 03 (ALA) & $0.3 \pm 0.1$ & $2.0 \pm 0.1$ & $0.7 \pm 0.1^{\mathrm{b}}$ \\
C20:5 03 (EPA) & $31.1 \pm 1.0$ & $27.8 \pm 1.2$ & $11.0 \pm 0.9^{\mathrm{a}, \mathrm{b}}$ \\
$\Sigma$ PUFA- $\omega 3$ & $31.4 \pm 0.6$ & $28.0 \pm 0.6$ & $11.7 \pm 0.5$ \\
C18:2 $\omega 6$ & $2.9 \pm 0.9$ & $3.2 \pm 0.1$ & $0.3 \pm 0.1^{\mathrm{a}, \mathrm{b}}$ \\
C18:3 $\omega 6$ (GLA) & $0.5 \pm 0.1$ & $0.1 \pm 0.1$ & $0.1 \pm 0.1$ \\
C20:3 $\omega 6$ & $1.1 \pm 0.1$ & $0.2 \pm 0.1$ & $0.6 \pm 0.1$ \\
C20:4 66 & - & $0.3 \pm 0.1$ & $0.2 \pm 0.1$ \\
$\Sigma$ PUFA- $\omega 6$ & $4.5 \pm 0.5$ & $4.3 \pm 0.2$ & $1.2 \pm 0.2$ \\
\hline
\end{tabular}

${ }^{a}$ Indicates that NTP is significantly different from control and ${ }^{\mathrm{b}}$ indicates that NTP is significantly different from sonication.

Note: ALA (alpha-linolenic-acid); EPA (eicosapentaenoic acid); GLA (gammalinolenic-acid); SFA (saturated fatty acids); MUFA (monounsaturated fatty acids); PUFA (polyunsaturated fatty acids). 
numerous electron-collision-dominated reactions that can fragment molecules into neutral and ionic products (Graham and Stalder, 2011). According to Jiang et al. (2014), the reaction of plasma with organic compounds can occur through three basic reaction mechanism: hydrogen abstraction, unsaturated electrophilic addition and electron transfer. In the case of compounds having aliphatic hydrocarbons such as lipids, the hydrogen abstraction is the primary mechanism for producing SFAs.

\section{Micrograph images of algal biomass after non- thermal plasma}

The aim of this experiment was to visualize the $N$. gaditana cells by microscopic techniques to ascertain the degree of disruption of the rigid algal cell wall. Micrographs of $N$. gaditana cells exposed to $10 \mathrm{~min}$ of NTP are shown in Figures 4 and 5. Microscope images of the cells after NTP-assisted extraction reveal the extent of the cell rupture. Scanning electron microscopic (SEM) and laser scanning confocal microscopic (LSCM) images confirmed that NTP is indeed a potent and effective method to induce cell disruption. There were large differences between the
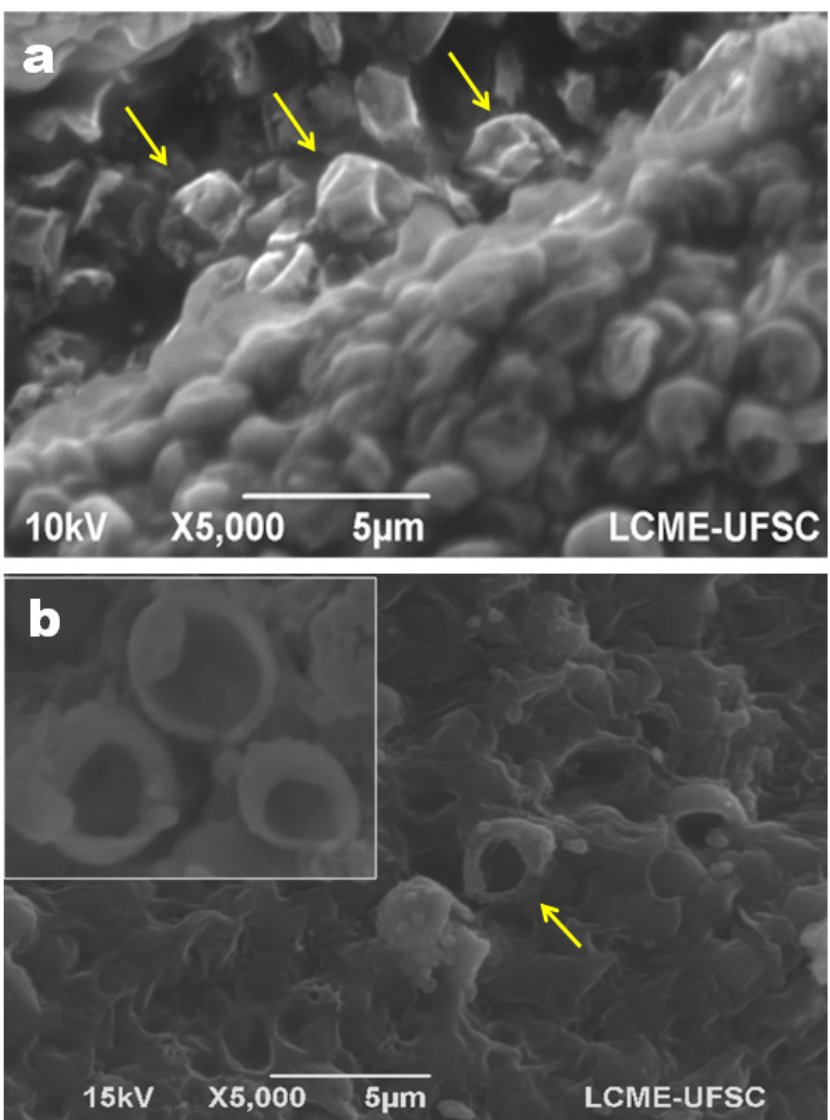

Figure 4. Scanning electron microscopy (SEM) of $N$. gaditana cells that were exposed to $10 \mathrm{~min}$ of NTP; (a) the image shows a non-uniform surface of algal cells that are apparently fractured; (b) N. gaditana cells showing large splits.
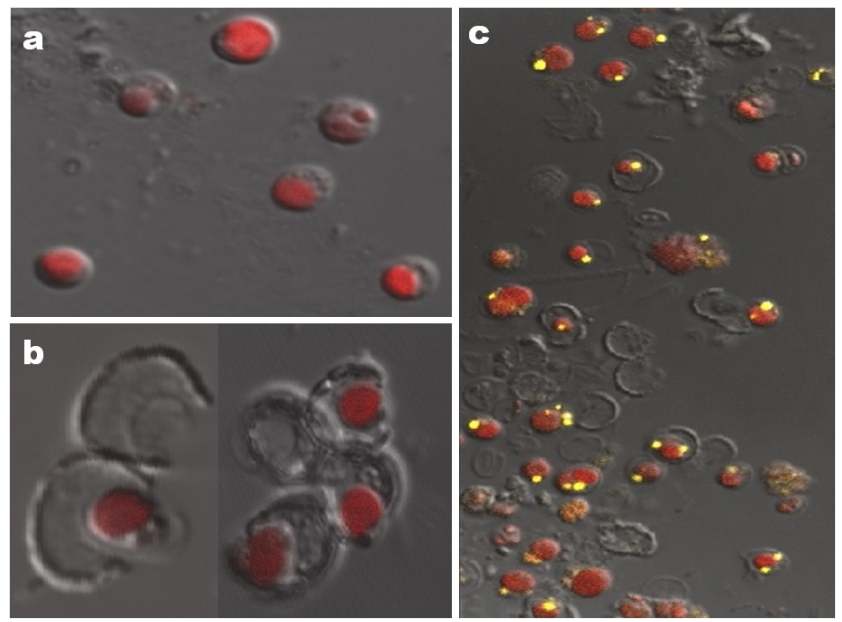

Figure 5. Laser scanning confocal microscopy (LSCM) of $N$. gaditana cells; (a) intact or untreated cells display red fluorescence from chlorophyll after UV excitation; (b) and (c) micrographs of cells after exposure to $10 \mathrm{~min}$ of NTP. Disrupted $N$. gaditana cells have large splits (b) and the mostly fractured algal cells show yellow oil droplets after Nile red staining (c). Algal cells viewed under 100x objective with 530 $\mathrm{nm}$ excitation wavelength and $575 \mathrm{~nm}$ emission filters. Scale bars $=5 \mu \mathrm{m}$.

untreated cells and cells that were exposed to NTP. The surface of the intact $N$. gaditana cells was smooth without apparent holes (Figure 5a), whereas after NTP treatment cells showed a non-uniform surface, were apparently fractured (Figure 4a), and had many pores with large fissures (Figures 4b and 5b).

Intracellular lipid bodies of the algal cells, after NTP treatment and staining with Nile Red, appear to be more readily extracted (Figure 5c). Interestingly, in Figure 5c there are some algal cells without the cell body, i.e., it appears that the matrix was released into the cytosol, and the stained-lipids are kept within the plasma membrane, which marks the boundary between the cell wall on the outside and the cytoplasm on the inside. These findings suggest that NTP can both change the surface of the algal cells and modify or lyse the cell, which would release the target lipid molecules (Figure 6).

Puértolas et al. (2016) studied PEF-assisted extraction of olive oil and reported that PEF causes the formation of pores in the cell membranes of plant tissues. This process, called electroporation and cavitation, enhances the diffusion of solutes through the cell membranes, facilitating the recovery of intracellular substances, including oil and other molecules of interest, such as polyphenols. As the mechanism of NTP may be similar to that of PEF, applying NTP on algal biomass could improve lipid recovery by a dual mechanism: lipid extraction from algal biomass through disruption of rigid algal cell walls, and the release of lipids trapped in the cellmembrane body. However, despite these positive 


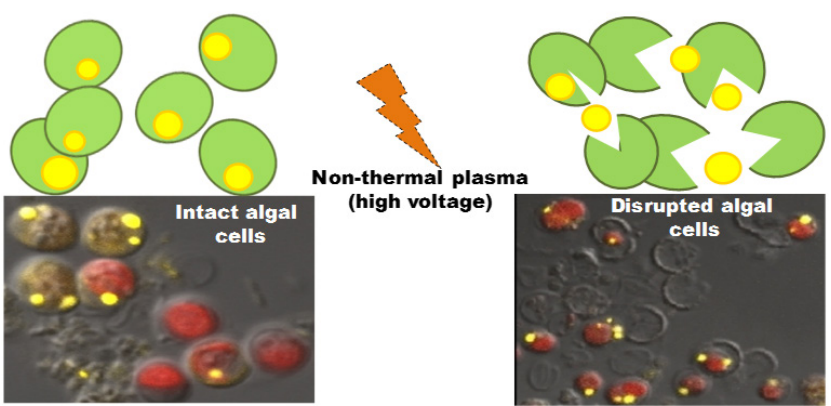

Figure 6. Scheme showing the action of non-thermal plasma on $N$. gaditana cells.

aspects of NTP for algal biomass, NTP also causes energy variation in adherent cell membrane/wall molecules, which may trigger radical formation and unwanted reactions such as oxidation that might reduce product quality (Mendes Pinto et al., 2001).

\section{Calculation of physical properties of biodiesel}

In order to assess the quality of biodiesel produced from $N$. gaditana biomass that has been subjected to NTP and sonication pretreatments, several physical properties of biodiesel were calculated using empirical formulas and compared with commercially used plant oil fatty acids (Jatropha and Palm) and with ASTM D6751 (USA) and EN 14214 (Europe) biodiesel fuel quality. The data indicate that the following physical properties of biodiesel from NTP-assisted extraction of $N$. gaditana comply with fuel standards and are comparable with plant oil fatty acids (Table 2).

The iodine value (IV) reflects the amount of unsaturation in the form of double bonds in the fatty acids. The higher the IV, the more $\mathrm{C}=\mathrm{C}$ bonds are present in the oil. Table 2 shows that the IV of $N$. gaditana oil in the control $(171.5 \mathrm{~g} \mathrm{I} / 100 \mathrm{~g})$ and after sonication $\left(154.7 \mathrm{~g} \mathrm{I}_{2} / 100 \mathrm{~g}\right)$ are higher than from NTP-assisted extraction $(83.6 \mathrm{~g} \mathrm{I} / 100 \mathrm{~g})$. This value is comparable to the IV of Jatropha oil $\left(96.5 \mathrm{~g} \mathrm{I}_{2} / 100\right.$ $\mathrm{g})$ and below the ASTM D6751 fuel standard maximal value of $120 \mathrm{~g} \mathrm{I}_{2} / 100 \mathrm{~g}$ oil.

The cetane number $(\mathrm{CN})$ is one of the most significant indicators for determining the combustion behavior of biodiesel (Islam et al., 2013). Since high $\mathrm{CN}$ ensures less ignition delay, better combustion and cold start properties with minimum white smoke, resulting in more efficient engine performance, higher CNs are more desirable (Knothe 2006; Islam et al., 2013). The highest cetane number $(\mathrm{CN}=53.0)$ was recorded in NTP treatment due to the higher content in SFAs (mainly C16:0), followed by sonication (CN $=34.8)$ and the control $(\mathrm{CN}=31.6)$, which are mainly composed of PUFAs, such as EPA. Most biodiesel fuels from vegetable oil sources have CNs in the high 40 s to lower 60s. Specifications for the minimum CN of biodiesel are 47 (ASTM D6751) and 51 (EN 14214).

Oxidation stability (OS) was calculated based on eicosapentaenoic acid ( $220: 5 \omega 3)$ content, the predominant fatty acid found in N. gaditana biomass. OS values for the different treatments decreased from $8.6 \mathrm{~h}$ (NTP) to $3.8 \mathrm{~h}$ (sonication) and $3.5 \mathrm{~h}$ (control). The standard minimum OS limits for biodiesel are $6 \mathrm{~h}$ in EN 14214 and IS-15607 (Yaakob et al., 2014) and 3 $h$ in ASTM D6751.

Since the differences in fatty acid profiles were manifested in different biofuel properties (Knothe, 2013), it is relevant to note the fatty acid profiles of the biodiesel derived from two common commodity oils: soybean oil consists of palmitic (10-11\%), stearic (4$6 \%$ ), oleic $(21-25 \%)$, linoleic $(50-55 \%)$ and linolenic $(8 \%)$ acids; while palm oil consists of palmitic (40$45 \%)$, stearic $(4-5 \%)$, oleic $(40 \%)$ and linoleic $(10 \%)$ acids, with smaller amounts of other fatty acids (Islam et al., 2013). As $N$. gaditana contains high amounts of PUFAs, biodiesel derived from oils with such a fatty acid profile would likely display both poor cold flow and poor OS. However, after applying NTP on $N$. gaditana biomass, palmitic acid appears to be the most common fatty acid, suggesting that cold flow and OS properties will be less problematic for biodiesel production from $N$. gaditana biomass.

\section{Correlated studies and future research}

The NTP-technology has notable advantages, but also limitations, while the exact mechanisms in the

Table 2. Comparison of physical properties of biodiesel produced from $N$. gaditana with vehicular biodiesel standards ASTM D6751 (USA) and EN 14214 (Europe), and the plant based biodiesels Jatropha oil methyl esters (JME) and palm oil methyl esters (PME).

\begin{tabular}{|c|c|c|c|c|c|c|c|}
\hline \multicolumn{3}{|l|}{ Quality parameters } & \multicolumn{3}{|c|}{ N. gaditana } & \multicolumn{2}{|c|}{ Plant oil methyl esters } \\
\hline Biodiesel property & $\begin{array}{l}\text { ASTM } \\
\text { D6751 }\end{array}$ & $\begin{array}{c}\text { EN } \\
14214\end{array}$ & Control & Sonication & NTP & PME & JME \\
\hline Saponification value (SV, mg KOH) & a & $\mathrm{a}$ & 187.4 & 193.0 & 194.5 & - & - \\
\hline Iodine value (IV, g I/2/100 g) (maximum) & 120 & 109.2 & 171.5 & 154.7 & 83.6 & 49.5 & 96.5 \\
\hline Cetane number (CN, minimum) & 47 & 51 & 31.6 & 34.8 & 53.0 & 61 & 54 \\
\hline Degree of unsaturation (DU, \% wt) & a & a & 103.8 & 96.5 & 61.3 & - & - \\
\hline Long-chain saturation factor (LCSF, \% wt) & a & a & 5.3 & 7.3 & 9.7 & - & - \\
\hline Cold filter plugging property $\left(\mathrm{CFPP},{ }^{\circ} \mathrm{C}\right)$ & a & $\leq 5 / \leq-20$ & 0.2 & 6.7 & 14.2 & 13 & -2 \\
\hline High heating value ( $\left.\mathrm{HHV}, \mathrm{MJ} \mathrm{kg}^{-1}\right)$ & a & $\bar{a}$ & 39.2 & 39.1 & 40.2 & - & - \\
\hline Oxidative stability (OS, hr) & 3 & $\geq 6$ & 3.5 & 3.8 & 8.6 & 16.5 & 3.8 \\
\hline
\end{tabular}

${ }^{a}$ No limit designated for the physical property. 
NPT reactor are not known. Characterization of the active species in the NTP water reaction with the algal biomass is not trivial, because of the short lifetime of the cocktail of active species that are formed. Jérome (2016) hypothesized that a reaction of radical species with the cellulose surface produces sugar radicals, ultimately leading to bond cleavages. In our study, NTP-induced morphological alterations of microalgae disrupt cell walls, causing lipids to diffuse within the bulk material. Therefore, Jérome (2016) proposed to use real time in-situ Fourier transform infrared (FT-IR) on the surface of oligosaccharides (depolymerization of cellulose into branched glucans) exposed to NTP to better understand how the active species react.

It is known that in air NTP creates a cocktail of highly excited species and radicals, but it is uncertain whether reactive species formed by NTP for algal biomass in water lead to hydrolysis or oxidation reactions between membrane lipids containing PUFAs and $\mathrm{O}_{2}, \mathrm{~N}_{2}, \mathrm{O}_{3}, \mathrm{H}^{\bullet}, \mathrm{HO}^{\bullet}, \mathrm{H}_{2} \mathrm{O}_{2}$ radicals. Although there is limited direct contact between the reactive radicals and cell surfaces in the aqueous environment of algal cells, a secondary role for such reactions cannot be ruled out (Fridman, 2008).

In the context of algal biodiesel production with NTP-technology, by adding methanol to the plasma reactor the transesterification reaction may occur inside the NTP reactor and form biodiesel (Cubas et al. 2016). It seems that three parameters are important to convert algal oil into biodiesel by NTP: $i$ ) the oil/ methanol molar ratio, $i i)$ the water concentration and iii) the reaction time, but much effort is needed to explore the potential of NTP in this field. Advancing our understating of the role of reaction time, algal cell wall chemistry and unsaturation of fatty acids will aid to further optimize the process.

\section{CONCLUSIONS}

This study investigated the application of NTP for $N$. gaditana biomass extraction on a laboratory scale and found that NTP-treatment causes considerable cell disintegration of this microalga. NTP may thus represent an alternative pretreatment method prior to algal lipid extraction. Our results also suggest that the high voltage of NTP can break the double bonds in PUFAs and convert them to single bonds, thereby producing SFAs. While more research is needed on the development and utilization of NTP for the algal bioprocess, NTP is a promising technology for algal cell disruption prior to lipid extraction and for biodiesel production.

\section{ACKNOWLEDGEMENTS}

The authors acknowledge UNISUL and financial support from FAPEU/SC (Fundação de Amparo à
Pesquisa e Extensão Universitária - Santa Catarina). AP Matos is grateful to CAPES (finance code 001) for a doctoral scholarship. The helpful laboratory support of the Laboratory of Physical-Chemical Analysis (LABCAL/UFSC) is also acknowledged.

\section{REFERENCES}

Ahmad, I., Fatma, Z., Yazdani, S.S., Kumar, S. DNA barcode and lipid analysis of new marine algae potential for biofuel. Algal Res., 2, 10-15 (2013). https://doi.org/10.1016/j.algal.2012.10.003

Alkawareek, M. Y., Gorman, S. P., Graham, W. G., Gilmore, B. F. Potential cellular targets and antibacterial efficacy of atmospheric pressure non-thermal plasma. Int. J. Antimicrob. Ag., 43, 154-160 (2014). https://doi.org/10.1016/j. ijantimicag.2013.08.022

Arora, N., Patel, A., Sartaj, K., Pruthi, P. A., Pruthi, V. Bioremediation of domestic and industrial wastewaters integrated with enhanced biodiesel production using novel oleaginous microalgae. Environ. Sci. Pollut. Res., 23, $20997-21007$ (2016). https://doi.org/10.1007/s11356-016-7320-y

Benoit, M., Rodrigues, A., Vigier, K. O., Fourré, E., Barrault, J., Tatibouet, J. M., Jérôme, F. Combination of ball-milling and non-thermal plasma atmospheric plasma as physical treatments for the saccharification of microcrystalline cellulose. Green Chem., 14, 2212-2215 (2012). https://doi.org/10.1039/c2gc35710k

Bligh, E. G., Dyer, W. J. A rapid method of total lipid extraction and purification. Can. J. Biochem. Phys., 37, 911-917 (1959). https://doi.org/10.1139/o59099

Borowitzka, M.A., Moheimani, N. R. Algae for biofuels and energy: Developments in Applied Phycology. Springer Science Business Media Dordrecht, p. 301 (2013). https://doi.org/10.1007/978-94-0075479-9

Chisti, Y. Biodiesel from microalgae. Biotechnol. Adv., 25, 294-306 (2007). https://doi.org/10.1016/j. biotechadv.2007.02.001

Cubas, A. L. V., Machado, M. M., Pinto, C. R. S. C., Moecke, E. H. S., Dutra, A. R. A., Biodiesel production using fatty acids from food industry waste using corona discharge plasma technology. Waste Manage., 47, 149-154 (2016). https://doi. org/10.1016/j.wasman.2015.05.040

Cubas, A. L. V., Machado, M. M., Santos, J. R., Zanco, J. J., Ribeiro, D. H. B., André, A. S., Debacher, N. A., Moecke, E. H. S. Effect of chemical species generated by different geometries of air and argon non-thermal plasma reactors on bacteria inactivation in water. Sep. Purif. Technol., 222, 68-74 (2019). https://doi.org/10.1016/j.seppur.2019.03.057 
Delaux, J., Nigen, M., Fourré, E., Tatibouet, J. M., Barakat, A., Atencio, L., Fernandéz, J. M. G., Vigier, K. D. O., Jérôme, F. Fast and solvent free polymerization of carbohydrates induced by non-thermal atmospheric plasma. Green Chem., 18, 3013-3019 (2016). https://doi.org/10.1039/ C5GC02773J

Franz, A. K., Danielwicz, M. A., Wong, D. M., Anderson, L. A., Boothe, J. R. Phenotypic screening with oleaginous microalgae reveals modulators of lipid productivity. ACS Chem. Biol., 8, 1053-1062 (2013). https://doi.org/10.1021/cb300573r

Fridman, A. Plasma chemistry. Cambridge University Press UK (2008). https://doi.org/10.1017/ CBO9780511546075

Gaunt, L.F., Beggs, C.B., Georghiou, G.E., Bactericidal action of the reactive species produced by gas-discharge nonthermal plasma at atmospheric pressure: a review. IEEE Trans. Plasma Sci. 34, 1257-1269 (2006). https://doi.org/10.1109/ TPS.2006.878381

Goettel, M., Eing, C., Gusbeth, C., Straessner, R., Frey, W. Pulsed electric field assisted extraction of intracellular valuables from microalgae. Algal Res., 2, 401-408 (2013). https://doi.org/10.1016/j. algal.2013.07.004

Graham, W. G., Stalder, K. R., Plasmas in liquids and some of their applications in nanoscience. J. Phys. D Appl. Phys., 44, 174037 (2011). https://doi. org/10.1088/0022-3727/44/17/174037

Gunerken, E., D'Hondt, E., Eppink, M. H. M., Garcia-Gonzalez, L., Elst, K., Wijffels, R. H. Cell disruption for microalgae biorefineries. Biotechnol. Adv., 33, 243-260 (2015). https://doi.org/10.1016/j. biotechadv.2015.01.008

Guillard, R. R. L. Culture of phytoplankton for feeding marine invertebrates. In: Smith, W. L., Charley, M. H. (ed) Culture of marine invertebrate animals. Plenum, New York (1975). https://doi. org/10.1007/978-1-4615-8714-9_3

Halim, R., Harum, R., Danquah, M. K., Webley, P. A. Microalgal cell disruption for biofuel development. Appl. Energ., 91, 116-121 (2012). https://doi. org/10.1016/j.apenergy.2011.08.048

Islam, M. A., Magnusson, M., Brown, R. J., Ayoko, G. A., Nabi, M. N., Heimann, K., Microalgal species selection for biodiesel production based on fuel properties derived from fatty acids profiles. Energies, 6. 5676-5702 (2013). https://doi. org/10.3390/en6115676

Istadi, N. A. S. A., Didi, D. A., Puput, M. S., Bambang, T. N. Biodiesel production from vegetable oil over plasma reactor: optimization of biodiesel yield using response surface methodology. B. Chem. React. Eng. Catal., 4, 23-31 (2009). https://doi. org/10.9767/bcrec.4.1.7115.23-31
Instituto Adolfo Lutz, Normas Analíticas do Instituto Adolfo Lutz - Métodos químicos e físicos para análise de alimentos. 3rd ed São Paulo: IMESP (2005).

Janczyk, P., Wolf, C., Souffrant, W. Evaluation of nutritional value and safety of the green micro-algae Chlorella vulgaris treated with novel processing methods. Arch. Zootech., 8, 132-147 (2005).

Jazzar, S., Carrillo, P. O., Ríos, A. P. L., Marzouki, M. N., Acién-Fernandez, F. G., Fernandéz-Sevilla, J. M., Molina-Grima, E., Smaali, I., Quesada-Medina, J. Direct supercritical methanolysis of wet and dry unwashed marine microalgae (Nannochloropsis gaditana) to biodiesel. Appl. Energ., 148, 210-219 (2015). https://doi.org/10.1016/j. apenergy.2015.03.069

Jérome, F. Non-thermal atmospheric plasma: Opportunities for the synthesis of valuable oligosaccharides from biomass. Curr. Opin. Green Sust. Chem., 2, 10-14 (2016). https://doi. org/10.1016/j.cogsc.2016.09.005

Jiang, B., Zheng, J., Qiu, S., Wu, M., Zhang, Q., Yan, Z., Xue, Q. Review on electrical discharge plasma technology for wastewater remediation. Chem. Eng. J., 236, 348-368 (2014). https://doi. org/10.1016/j.cej.2013.09.090

Lee, J. Y., Yoo, C., Jun, S. Y., Ahn, C. Y., Oh, H. M. Comparison of several methods for effective lipid extraction from microalgae. Bioresour. Technol., 101， 75-77 (2010). https://doi.org/10.1016/j. biortech.2009.03.058

Liao, X., Liu, D., Xiang, Q., Ahn, J., Chen, S., Ye, X., Ding, T. Inactivation mechanisms of non-thermal plasma on microbes: A review. Food Control, 75, 83-91 (2017). https://doi.org/10.1016/j. foodcont.2016.12.021

Kim, H. H., Non-thermal plasma processing for airpollution control: a historical review, current issues, and future prospects. Plasma Process Polym., 1, 91-110 (2004). https://doi.org/10.1002/ ppap. 200400028

Knothe, G. Analyzing biodiesel: standards and other methods. J. Am. Oil Chem. Soc., 83, 823-833 (2006). https://doi.org/10.1007/s11746-006-5033-y

Knothe, G. Production and properties of biodiesel from algal oils. In: Borowitzka, M. A., Moheimani, N. R. (ed.) Algae for biofuels and energy: Developments in Applied Phycology. Springer Science Business Media Dordrecht (2013). https:// doi.org/10.1007/978-94-007-5479-9_12

Ma, R., Wang, G., Tian, Y., Wang, K., Zhang, J., Fang, J. Non-thermal plasma-activated water inactivation of food-borne pathogen of fresh produce. J. Hazard Mater., 300, 643-651(2015). https://doi. org/10.1016/j.jhazmat.2015.07.061 
Martínez, J. M., Luengo, E., Saldana, G., Álvarez, I., Raso, J. C-phycocyanin extraction assisted by pulsed electric field from Arthrospira platensis. Food Res. Int., 99, 1042-1047 (2017). https://doi. org/10.1016/j.foodres.2016.09.029

Matos, A. P., Feller, R., Moecke, E. H. S., Sant'Anna, E. S. Biomass, lipid productivities and fatty acids composition of marine Nannochloropsis gaditana cultured in desalination concentrate. Bioresour. Technol., 197, 48-55 (2015). https://doi. org/10.1016/j.biortech.2015.08.041

Matos, A. P., Feller, R., Moecke, E. H. S., Oliveira, J. V., Furigo Junior, A., Derner, R. B., Sant'Anna, E. S. Chemical characterization of six microalgae with potential utility for food application. J. Am. Oil Chem. Soc., 93, 963-972 (2016). https://doi. org/10.1007/s11746-016-2849-y

Matos, A. P. The impact of microalgae in food science and technology. J. Am. Oil Chem. Soc., 94, 1333-1350 (2017). https://doi.org/10.1007/s11746-017-3050-7

McMillan, J. R., Watson, I. A., Ali, M., Jaafar, W. Evaluation and comparison of algal cell disruption methods: Microwave, waterbath, blender, ultrasonic and laser treatment. Appl. Energ., 103, 128-134 (2013). https://doi.org/10.1016/j. apenergy.2012.09.020

Mendes Pinto, M. M., Raposo, M. F. J., Bowen, J., Young, A. J., Morais, P. Evaluation of different cell disruption processes on encysted cells of Haematococcus pluvialis: effects of astaxanthin recovery and implications for bio-availability. J. Appl. Phycol., 13, 19-24 (2001). https://doi. org/10.1023/A:1008183429747

Mitra, M., Patidar, S. K., George, B., Shal, F., Maishra, S. A euryhaline Nannochloropsis gaditana with potential for nutraceutical and biodiesel production. Algal Res., 8, 161-167 (2015). https:// doi.org/10.1016/j.algal.2015.02.006

Pandiyaraj, K. N., Deshmukh, R. R., Arunkumar, A., Ramkumar, M. C., Ruzybayev, I., Shah, S. I., Su, P. G., Periayah, M. H., Halim, A. S. Evaluation of mechanism of non-thermal plasma effect on the surface of polypropylene films for enhancement of adhesive and hemo compatible properties. Appl. Surf. Sci., 347, 336-346 (2015). https://doi. org/10.1016/j.apsusc.2015.04.097

Phukan, M. M., Chutia, R. S., Konwar, B. K., Katati, R. Microalgae Chlorella as a potential bio-energy feedstock. Appl. Energ., 88, 3307-3312 (2011). https://doi.org/10.1016/j.apenergy.2010.11.026

Postma, P. R., Miron, T. L., Olivieri, G., Barbosa, M. J., Wijffels, R. H., Eppink, M. H. M. Mild disintegration of the green microalgae Chlorella vulgaris using bead milling. Bioresour. Technol., 184, 297-304 (2015). https://doi.org/10.1016/j. biortech.2014.09.033
Puértolas, E., Alvarez-Sabatel, S., Cruz, Z. Pulsed electric field: groundbreaking technology for improving olive oil extraction. Infom AOCS (Champaign) Int. News Fats Oils Relat. Mat., 27, 12-14 (2016). https://doi.org/10.21748/ inform.03.2016.06.12

Ragni, L., Berardinelli, A., Vannini, L., Montanari, C., Sirri, F., Guerzoni, M. E., Guarnieri, A. Nonthermal atmospheric gas plasma device for surface decontamination of shell eggs. J. Food Eng., 100, 125-132 (2010). https://doi.org/10.1016/j. jfoodeng.2010.03.036

Samarasinghe, N., Fernando, S., Lacey, R., Faulkner, W. B. Algal cell rupture using high pressure homogenization as a prelude to oil extraction. Renew. Energ., 48, 300-308 (2012). https://doi. org/10.1016/j.renene.2012.04.039

Siqueira, S. F., Francisco, É. C., Queiroz, M. I., Menezes, C. R. de, Zepka, L. Q., Jacob-Lopes, E. Third generation biodiesel production from microalgae Phormidium autumnale. Braz. J. Chem. Eng., 33, 427-433 (2016). https://doi. org/10.1590/0104-6632.20160333s20150134

Show, K. Y., Lee, D. J., Tay, J. H., Lee, T. M., Chang, J. S. Microalgal drying and cell disruption - Recent advances. Bioresour. Technol., 184, 258-266 (2013). https://doi.org/10.1016/j. biortech.2014.10.139

Yaakob, Z., Narayanan, B. N., Padikkaparambil, S., Unni, S., Akbar, M. P. A review on the oxidation stability of biodiesel. Renew. Sust. Energ. Rev., 35, 136-153 (2014). https://doi.org/10.1016/j. rser.2014.03.055

Yap, B. H. J., Dumsday, G. J., Scales, P. J., Martin, G. J. O. Energy evaluation of algal cell disruption by high pressure homogenization. Bioresour. Technol., 184, 280-285 (2015). https://doi.org/10.1016/j. biortech.2014.11.049

Yepez, X. V., Keener, K. M. High-voltage Atmospheric Cold Plasma (HVACP) hydrogenation of soybean oil without trans-fatty acids. Innov. Food Sci. Emerg. Technol., 38, 169-174 (2016). https://doi. org/10.1016/j.ifset.2016.09.001

Zhang, Y., Yu, Q., Wang, Y. Non-thermal atmospheric plasmas in dental restoration: Improved resin adhesive penetration. J. Dent., 42, 1033-1042 (2014). https://doi.org/10.1016/j. jdent.2014.05.005

Zhang, H., Ma, D., Qiu, R., Tang, Y., Du, C. Non-thermal plasma technology for organic contaminated soil remediation: A review. Chem. Eng. J., 313, 157-170 (2017). https://doi.org/10.1016/j.cej.2016.12.067

Zhu, C. J., Lee, Y. K., Determination of biomass dry weight of marine microalgae. J. Appl. Phycol., 9, 189-194 (1997). https://doi. org/10.1023/A:1007914806640 